Faculty of Philosophy

University of Ss. Cyril \& Methodius in Skopje

ratko.duev@gmail.com

\title{
ORGANON. TRACING THE NAME OF AN UNKNOWN MUSICAL INSTRUMENT IN THE BIBLE
}

\begin{abstract}
Studies of the Old Testament musical instrument ugab have remained unclear to this day, as can be seen in translations of the Bible into all European languages. Research of written and archaeological evidence suggests the the term organon may denote a specific musical instrument - a sort of a long (narrow) flute.
\end{abstract}

1. If we conduct a comparative philological analysis of the earliest translations of the Bible, we may ascertain from the way in which the terms for musical instruments were translated and adapted that the translators and editors of these texts experienced great difficulties in identifying such musical instruments. The reasons for such difficulties include: the great time distance between the oldest original texts and the first translations of the Bible; the development of musical instruments in different environments over the centuries; and the perishable quality of the organic materials from which these instruments were made.

The problem of identifying these instruments is particularly evident if we analyze the term öpravov, which was used to translate the name of the musical instrument ' $\hat{u} g \bar{a} \underline{b}^{1}$ in the Greek translation of the Old Testament (The Septuagint), in comparison with the Latin translation (The Vulgate) - both of which translations served as a basis for all other translations into the languages of the European peoples.

${ }^{1}$ The different Latin transcriptions are due to the inability to properly render the Hebrew letters in Latin. There are many different rules for Latin transliteration and transcription of Hebrew letters, so the text uses generally accepted principles (cf. S. Haik-Ventoura, The Music of the Bible Revealed, Bibal Press, Berkeley 1991; M. L. West, The East Face of Helicon: West Asiatic Elements in Greek Poetry and Myth, Oxford 1997, xxi - xxiv; for the latest transliteration used in table 1 see J. Braun, Music in Ancient Israel/Palestine: archaeological, written, and comparative sources, Cambridge 2002; D. N. Freedman, A. C. Myers, B. A. Beck (edd.), Eerdmans Dictionary of the Bible, Wm. B. Eerdmans Publishing Co. 2000. 
2. But why have translators decided to use this term? In ancient Greek, the basic meaning of the word op $p$ qvov can be translated as 'tool or instrument', that is 'a musical instrument'. Analysis shows that with the basic meaning of 'tool, instrument', is correctly translated in the "Second Book of Maccabees". The most accurate translation of the Hebrew kélimm and $k^{e} l \bar{e}^{-5}$ 'musical instruments' with the plural of the word - $\tau \dot{\alpha}$ ó $\rho \gamma \alpha v \alpha$ whose translation as a transcription is accepted in both the Latin Vulgata and the Old Slavic translation of the Bible $^{6}$. Likewise the Hebrew minnîm (Ps. 150:4) 'stringed musical instruments' translates exactly as $\chi o \rho \delta \alpha i \varsigma$, respectively cordis 'in/on strings'?

Confusion emerged when the translators of The Septuagint attempted a translation and adaptation into Greek of the musical instrument ugab. In Genesis 4:21, this term was translated as $\psi \alpha \lambda \tau \eta \dot{\rho} \rho \imath o v$; in Job 21:12 and 30:31, it was translated as $\psi \alpha \lambda \mu o ́ s$, 'a song' sung accompanied by a string instrument; while in Psalm 150:4, it is translated simply as óp rovov, that is, a 'musical instrument'(see Table 1). All this indicates that the translators considered of $\rho \alpha$ vov a type of string instrument, most probably guided by Psalm 150:4 in which ugab is preceded by minnim, and the same can be identified in the translation of the Jewish kinnor and nébel ${ }^{8}$ in Amos 5:23 and 6:5 and Psalm 136 (137):2 as $o \rho \gamma \alpha v \alpha(o ̈ \rho \gamma \alpha v \omega v)$. We can deduce from this that the term was used to denote an unknown musical instrument, as can be observed in the translation of the Jewish "a sêb rôsîm, 2 Kings 6:5-a type of rattle made of the wood of the cypress tree. ${ }^{9}$

The translation for this term is much more accurate in the Latin Vulgate, unlike the Old Slavic translation which uses the same terms as the Greek. The translators of the Vulgata translate only the word

${ }^{2}$ P. Chantraine, Dictionnaire etymologique de grecque langue, Paris 1968, s.v. óprovov, 815. Plato uses it with the meaning of a musical instrument (Rep. 397a, 399c-e), as a mythical instrument of Marsyas (Sym. 215c).

${ }^{3} 12: 15-27,13: 5$.

${ }^{4} 1$ Ch. 23:5.

${ }^{5} 1$ Ch. 15:16, 16:5-42; 2 Ch. 5:13, 7:6, 23:13, 29:26-27, 30:21, 34:12; Ps. 71:22; Amos 6: 5; Neh. 12:36. The appellative $k^{e} l \bar{e}$ - even appears 11 times as musical instruments of the Levites for the needs of the temple, but it also appears in function praise of the king (2 Ch. 23:13), prayer (Ps. 71:22) and as a musical instrument made by King David (Amos 6:5). For different interpretations of the etymology of $k^{e} l i$ see G. J. Botterweck, H. Ringgren, H.-J. Fabri, Old Testament Theological Dictionary, Grand Rapids 1974-.

${ }^{6}$ with few exceptions: 1 . Ch. 6:17, 2 Kings 6:14.

${ }^{7}$ Minnîm is connected to Syrian minā and Akkadian manānu 'fiber, wire, string' (W. L. Koehler, W. Baumgartner, J. J. Staum, Hebräisches und Aramäisches Lexicon zum Alten Testament, vols. 1-4, Leiden 1967-90, s.v.).

${ }^{8}$ On the type and problems with the identification of these stringed instruments see more extensively R. Duev, "The Psalter of the Psalmist David," Annuaire de la Faculté de Philosophie, Skopje 58, 2005, pp. 231-241.

${ }^{9} \mathrm{~J}$. Braun, 2002, 12. 
ugab as organum, which can be seen in Psalm 136:2, where the translation made according to the Septuaginta - kinnôr is translated as organa, and according to the Hebrew version as citharas.

3. What kind of musical instrument does the ugab represent? Intense archaeological excavations carried out in the Eastern Mediterranean, especially in Canaan in the last few decades, which have brought to light a wealth of material evidence of the type of musical instruments of the ancient East. However, precisely identifying many Bible instruments remains speculative, and has only increased the number of assumptions. The problem that translators and editors have had in the past is, in fact, a problem in modern science. Undoubtedly, as the first musical instrument mentioned in Gen. 4:21, along with the kinnôr, this instrument had particular significance in the music of ancient Israel. While kinnor is the most commonly cited musical instrument in the Old Testament, the $u g a b$ is mentioned only three times: in mourning in Job 30:31, as an instrument of the wicked in Job 21:12, and as an instrument of praising God in Psalm 150:4. ${ }^{10}$

Numerous attempts, both etymological and historical, have been made over the past few decades to identify this musical instrument, variously claiming the instrument to be a type of flute, a tambour, or a harp. However, I believe that C. Sachs's claim that the ugab was a type of a narrow flute is the most acceptable solution to this problem. ${ }^{11}$ Sach's conclusion is based on the premise that many flutes produced a sound which contained the onomatopoeic vocal $u-u$ and that it was the flute which was most commonly associated with expressions of love, passion and other strong desires. ${ }^{12}$

4. The flute is one of the oldest musical instruments in the history of mankind ${ }^{13}$. Bone flutes with one or more finger-holes have been found across several Paleolithic, Mesolithic, and Neolithic archaeological sites ${ }^{14}$. This is further confirmed by the 1997 discovery of Slovenian paleontologist Ivan Turk, who dates a piece of bone flute between 43,000 and 67,000 BC. ${ }^{15}$ The existence of this type of wind instrument

10 Although the Jewish version of Psalm 151 found in the Dead Sea Scrolls (11QPsApa 151) may also be mentioned in this context, it dates from much later time (ca. 1st century AD), thus making it very difficult to relate to the above mentioned older texts.

${ }^{11}$ C. Sach, The History of Musical Instruments, New York 1940; cf. D. N. Freedman, A. C. Myers, B. A. Beck (ed.), Eerdmans Dictionary of the Bible, Wm. B. Eerdmans Publishing Co. 2000, 929.

12 There is an assumption that the term el-hanhilot as a mark of Psalm 5 means 'for flutes', which means that this psalm was sung with flutes (S. Haik-Ventoura, 1991, 417), but it may still indicate the color of the sound (Cf. A. Schaeffner, Origins of Musical Instruments, Paris 1968, 270s.).

${ }^{13}$ M. L. West, "Music Therapy in Antiquity," in P. Horden (ed.), Music as Medicine. The History of Music Therapy since Antiquity, Aldershot, 2000, 51-63.

${ }^{14}$ A. Baines, Woodwind Instruments and their History, 3rd ed., London 1967, 171s.

${ }^{15}$ The Times, 5 April 1997. 
is widely referred to in the Eastern Mediterranean and especially in Egypt as $m a{ }^{\prime} t,{ }^{16}$ less frequently in Sumer as tigi, and later in Israel as nay. In the Aegean this instrument only appeared in Hellenism, ${ }^{17}$ but even then its popularity was negligible. ${ }^{18}$ It appears as iynx, which is also the name of a bird species, plagiaulos, and possibly as photinx. ${ }^{19}$

5. With regards to the translation of the Hebrew ugab in the Old Church Slavic edition of The Bible, we may observe that the translators accepted in their entirety the solutions contained in The Septuagint. Due to the many redactions over the centuries of translations of the Holy Scriptures, it is difficult to determine the original translations made by Saints Cyril and Methodius and the translations made at the Ohrid Literary Center. The Psalter is one of the earliest parts of the Bible to be translated into Old Church Slavonic, ${ }^{20}$ and most of the musical instruments in the Bible are mentioned there. It is highly likely that the translation and the manner of the adaptation of these terms were the work of the Holy Brothers Cyril and Methodius themselves ${ }^{21}$. Studies of the language of the Psalter demonstrate that after the initial translation the text was issued in at least 6 different editions in the period between the $11^{\text {th }}$ and $14^{\text {th }}$ centuries. However, no observable difference in the terms for the musical instruments was discovered amongst the variations in each manuscript. ${ }^{22}$

6. Analysis of the translation of the Jewish term for the musical instrument $u g a b$ in the Macedonian edition of the Bible reveals that the translators in this particular case did not follow the examples of the Old Slavonic translation and its source The Septuagint, but relied more on the Vulgate. ${ }^{23}$ In this, the Macedonian translators of the

${ }^{16}$ For the Egyptian long flute, see L., Manniche, Music and Musicians in Ancient Egypt, London: British Museum Press 1991, 28.

${ }^{17}$ M. L. West, Ancient Greek Music, Oxford 1992, 112.

${ }_{18}$ Most likely the unpopularity of long flutes in the Aegean is the reason why Old Testament translators could not imagine the existence of such an instrument in ancient Israel.

${ }^{19}$ Hesychius defined it as a 'syrinx, aulos, a sort of trumpet,' perhaps intending to describe it as a wind instrument that does not have a pointed reed mouthpiece.

${ }^{20}$ According to Nestor's chronology it was translated by Constantine (Cyril) and Methodius (898, or 863 and 869 ).

${ }^{21}$ The analysis of the first Slavic Glagolitic script created by Constantine showed that besides the symbolism in the characters themselves, its creator was an exceptional person with knowledge of almost all the scripts that existed at the time. The adaptation of several Semitic signs in the Glagolitic script indicates that its creator knew the Hebrew language (П. Хр. Илиевски, Појава и развој на писмото со посебен осврт кон почеточите на словенската писменост, МАНУ, Скопје 2001, 123). In missions through the Slavic territory and life spent with the Slavs he had the opportunity to get better acquainted with their folklore and their musical instruments.

${ }^{22}$ C. M. MacRobert, "The Textual Tradition of the Church Slavonic Psalter up to the Fifteenth Century," in J. Krašovec ed., Interpretation of the Bible, Slovenska akademija znanosti in umetnosti - Sheffield Academic Press 1998, 921-940.

${ }^{23}$ The same, with minor modifications, can be observed in the more recent Russian, Serbian, and Bulgarian revised versions of the Bible (cf. Tab.): Russian 'svirali, organ'; 
Old Testament were most probably influenced by their comparison of German, English and the French translations based on the Vulgate. This influence can be observed in Psalm 136 (137):2 where organon/kinnôr is translated as 'harp - harfa' (Luther Bible: harfen), because if they had taken into account the Hebrew term kinnor $r$, then the more likely translation would have been 'gusla', as this musical term is most commonly translated. In the same manner, organon would have been translated with 'svirka'. Further on, the same term is translated in Psalm 151:2 as 'citra' or zither, a medieval instrument characteristic of Western European countries. A more precise translation of $t a$ organa - with few exceptions - is 'svirki', meaning 'musical instruments'. ${ }^{24}$

7. In fact, if we take into account the history and development of Macedonian musical instruments, the mistranslation and adaptation of the Jewish term ugab as organon in The Septuagint would be brought closest to its original meaning if we used the word kaval (a type of long flute) ${ }^{25}$ In the latest and revised standard version (RSV) of the German Bible, and in particular in the English Bible, ugab is translated as flötenspiel in German (Genesis 4:21), and as pipe in English (Genesis 4:21; Job 21:12, 30:31; Psalms 150:4) rather than organ as in older editions. The term organ came to denote a specific musical instrument (organa, hydraulis in Greek) and thus was unsuitable as a translation of the name of this ancient instrument.

Serbian 'svirači, svirala, organ'; Bulgarian 'svirka, svirki,' but in Genesis 4:21 ugab is a translation as kaval; in the Croatian version as 'sviralo' but in Job 31:30 as frula. The only translation is more consistent in the Slovenian version where ugab is translated as flavto/e, with the exception of piščal in Psalm 150:4.

${ }^{24}$ Svirki does not of course refer to the name of the type of aerophonic musical instruments (cf. А. Линин, Народните музички инструменти, Скопје 1986, 61, 62, 87), but a translation of the Latinized term "muzički instrumenti (musical instruments)", which is an attempt to bring it under folk terminology, derived from Macedonian sviri, svirači, analogous their instruments are svirki.

${ }^{25}$ Type of long flute, one of the most popular folk musical instruments in Macedonia in the past, although the name kaval has a Turkish origin, widely spread throughout the Balkans (A. Gojković, Narodni muzički instrumenti, Vuk Karađić 1989, sv. kaval). 
Table 1.

\begin{tabular}{|c|c|c|c|c|c|}
\hline \multicolumn{6}{|c|}{ 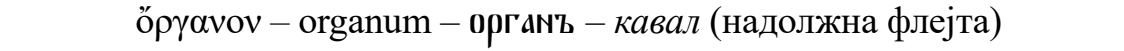 } \\
\hline & Septuaginta & Vulgata & БНБлН' & $\begin{array}{c}\text { Свето } \\
\text { Писмо }\end{array}$ & $\begin{array}{c}\text { Biblia } \\
\text { Hebraica }\end{array}$ \\
\hline Gen. $4: 21$ & $\psi \alpha \lambda \tau \eta ́ \rho ı v ~$ & organo & пьвмнцб & свирачи & 'ug $\underline{g} \bar{b} \underline{b}$ \\
\hline $\begin{array}{l}2 \text { Kings } 6 \text { : } \\
5\end{array}$ & ópróvors & / & оргаNъI & свирки & ${ }^{a}$ sêb rôšî̀m \\
\hline Job $21: 12$ & $\psi \alpha \lambda \mu о \tilde{v}$ & organi & П'СсNH & свирки & $\hat{u} \underline{g} \bar{a} \underline{b}$ \\
\hline Job $30: 31$ & $\psi \alpha \lambda \mu o ́ \varsigma$ & organum & п'tcNb & свирките & 'ug $g \bar{a} \underline{b}$ \\
\hline $\begin{array}{l}\text { Ps. } 136 \\
(137): 2\end{array}$ & ö $\rho \gamma \alpha v \alpha$ & $\begin{array}{c}\text { organa } \\
\text { (citharas) }\end{array}$ & шргамы & харфи & kinnôr \\
\hline Ps. $150: 4$ & 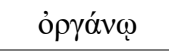 & organo & 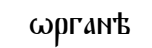 & свирка & $\mathrm{MИ}+{ }^{\prime} \hat{u} \underline{g} \bar{a} \underline{b}$ \\
\hline Ps. $151: 2$ & öpravov & organum & шргаNz & цитра & $\hat{u} g \bar{g} a ̄ b$ \\
\hline Amos $5: 23$ & ö $\rho \gamma \alpha v \omega v$ & lyrae & $\omega р г а N \omega в ъ$ & гусла & nēbel \\
\hline Amos $6: 5$ & öp $\gamma \alpha v \omega v$ & psalterii & / & гусла & $n e \bar{b} e l+\mathrm{MИ}$ \\
\hline
\end{tabular}

\section{BIBLIOGRAPHY}

Baines, A., Woodwind Instruments and their History, 3rd ed., London 1967.

Botterweck, G. J., Ringgren, H., Fabri, H.-J., Old Testament Theological Dictionary, Grand Rapids 1974-.

Braun, J., Music in Ancient Israel/Palestine: archaeological, written, and comparative sources, Cambridge 2002.

Chantraine, P., Dictionnaire etymologique de grecque langue, Paris 1968.

Дуев, Р., „Псалтирот на псалмописецот Давид,“ Годишен зборник на Филозофскиот факултет во Скопје 58, 2005, pp. 231-241.

Freedman, D. N., Myers, A. C., Beck, B. A. (edd.), Eerdmans Dictionary of the Bible, Wm. B. Eerdmans Publishing Co. 2000.

Gojković, A., Narodni muzički instrumenti, Vuk Karađić 1989,

Haik-Ventoura, S., The Music of the Bible Revealed, Bibal Press, Berkeley 1991.

Илиевски, П. Хр., Појава и развој на писмото со посебен осврт кон почеточите на словенската писменост, МАНУ, Скопје 2001.

Koehler, W. L., Baumgartner, W., Staum, J. J., Hebräisches und Aramäisches Lexicon zum Alten Testament, vols. 1-4, Leiden 1967-90.

Линин, А., Народните музички инструменти, Скопје 1986.

MacRobert, C. M., 'The Textual Tradition of the Church Slavonic Psalter up to the Fifteenth Century,' in J. Krašovec (ed.), Interpretation of the Bible, Slovenska akademija znanosti in umetnosti - Sheffield Academic Press 1998, pp. 921-940. 
Manniche, L., Music and Musicians in Ancient Egypt, London: British Museum Press 1991.

Sach, C., The History of Musical Instruments, New York 1940.

Schaeffner, A., Origins of Musical Instruments, Paris 1968.

West, M. L., Ancient Greek Music, Oxford 1992.

West, M. L., The East Face of Helicon: West Asiatic Elements in Greek Poetry and Myth, Oxford 1997.

West, M. L., 'Music Therapy in Antiquity,'in P. Horden (ed.), Music as Medicine. The History of Music Therapy since Antiquity, Aldershot, 2000, pp. 51-63. 
